\title{
Mapping of Local Wisdom of West Nusa Tenggara to Developing Ecology Textbook
}

\author{
${ }^{1}$ Hunaepi ${ }^{2}$ Nova Kurnia ${ }^{3}$ Laras Firdaus \\ ${ }^{1,3}$ Dosen Prodi Pendidikan Biologi FPMIPA IKIP Mataram, Indonesia ${ }^{2}$ Dosen Prodi \\ Pendidikan Kimia FPMIPA IKIP Mataram, Indonesia \\ ${ }^{1}$ hunaepibio@ymail.com ${ }^{2}$ novakimia88@yahoo.com ${ }^{3}$ firdaus.coolguy@gmail.com
}

\begin{abstract}
West Nusa Tenggara is a province consisting of various tribes including Sasak, Samawa and Mbojo. Various cultures born of the lives of the people who later became a local wisdom. Local wisdom has wise values that can be integrated in learning activities, one of them in the course of ecology. However, based on empirical studies that obtained the integration of local wisdom, especially in the subject of ecology has not been done by the lecturers. To perform such integration, it is necessary to do the mapping of local wisdom which is expected to become the basis of the development of ecology textbook. The results of the mapping that has been done such as in Lombok Island there are habits of the people to take care of rice plants by placing the combustion of worms nyale (Eunica fucata) whose scent to insects, and on Sumbawa Island known tradition keep the forbidden forest by indigenous communities who once held when they hunting and find medicinal plants. The values of local wisdom is very important to be maintained, so values of local wisdom in NTB can be mapped and preserved, that results can be used as the basis of the development of ecology textbooks so that the integration of the local wisdom values in the learning process can be achieved.
\end{abstract}

Keywords: local wisdom, ecology textbook

\section{Pendahuluan}

Provinsi Nusa Tenggara Barat terdiri atas dua pulau besar yaitu Pulau Lombok dan Pulau Sumbawa. Kedua pulau tersebut dihuni oleh penduduk asli yang berbeda satu sama lain. Suku Sasak mendiami Pulau Lombok dan Suku Sambawa dan Mbojo di Pulau Sumbawa. Kehidupan dari suatu masyarakat melahirkan banyak kebudayaan dalam berbagai aspek. Kebudayaan ini merupakan kearifan lokal yang sanagat berharga dan penting untuk dipertahankan.

Kearifan lokal adalah koleksi fakta, konsep, kepercayaan, dan persepsi masyarakat ihwal dunia sekitar. Ini mencakup cara mengamati dan mengukur alam sekitar, menyelesaikan masalah, dan memvalidasi infomasi. Keraf (2002) mengatakan bahwa kearifan lokal adalah semua bentuk pengetahuan, keyakinan, pemahaman atau wawasan serta adat kebiasaan atau etika yang menuntut prilaku manusia dalam kehidupan di dalam komunitas ekologis. Sedangkan Ibrahim (2014) menyatakan kearifan lokal (local wisdom), dapat dipahami sebagai gagasan-gagasan, nilai-nilai, pandangan-pandangan setempat (lokal) yang bersifat bijaksana, penu kearifan, bernilai baik, yang tertanam dan diikuti oleh anggota masyarakat. Singkatnya kearifan lokal adalah proses bagaimana pengetahuan dihasilkan, disimpan, diterapkan, dikelola, dan diwariskan. Ada beberapa ciri kearifan lokal yaitu : (1) berdasarkan pengalaman, (2) teruji setelah digunakan berabad-abad, (3) dapat diadaptasi dengan kultur kini, (4) padu dalam praktek keseharian masyarakat dan lembaga, (5) lazim digunakan oleh individu atau masyarakat secara keseluruhan, (6) bersifat dinamis dan terus berubah, (7) sangat terkait dengan sistem kepercayaan (Al Wasilah et al., 2009). 
Jika mengkaitkan antara ciri-ciri kearifan lokal dengan sains, tampak beberapa poin memiliki kesamaan. Diantaranya ciri kearifan lokal berdasarkan pengalaman dan teruji setelah digunakan beradab-abad. Pengalaman ini bersumber dari kebiasaan orang-orang dulu untuk melakukan sesuatu misalnya pengobatan dengan tanaman tertentu yang efektif meredakan sakit meski saat itu mereka belum memahami ilmu pengetahuan. Hal ini merupakan suatu perilaku sains yang memang harus berdasarkan pengalaman dengan adanya suatu pembuktian, misalnya dalam bentuk eksperimen atau percobaan.

Kearifan lokal sebagai sumber pembelajaran sains (biologi, kimia dan fisika) akan lebih bersifat kontekstual. Pengembangan pembelajaran dengan berbasis kearifan lokal sangat membantu proses belajar peserta didik dan mengajar guru (Susanti, 2013). Beberapa penelitian lain yang telah menggunakan kearifan lokal daerahnya diantaranya Suardana (2010) yang mengembangkan suatu model praktikum kimia dasar berbasis budaya Bali untuk mahasiswa pendidikan kimia. Konsep praktikum ini mengacu kepada fenomena budaya Bali seperti: a) penentuan kadar basa dari awon (Bahasa Bali yang artinya abu dapur) sebagai pestisida alami masyarakat Bali dan b) konsep Apah (plasma dasar) dalam Bhuwana Alit (tubuh manusia) sebagai larutan buffer. Selain itu Sudiatmika (2010) juga mengembangkan suatu alat ukur tes literasi sains dalam konteks budaya Bali. Laporan dari Kurnia et al (2016) juga menyebutkan potensi pangan khas Lombok, Nusa Tenggara Barat dapat dijadikan sebagai kasus untuk perkuliahan kimia bahan makanan. Oleh karena itu, potensi kearifan lokal dapat dimanfaatkan untuk topik perkuliahan.

Ekologi sebagai salah satu bagian dari ilmu biologi mempelajari tentang bagaimana mahluk hidup dapat mempertahankan kehidupannya dengan megadakan hubungan antar mahluk hidup dan dengan benda tidak hidup di dalam tempat hidunya atau lingkungannya. Haekel (1866) ekologi adalah ilmu komprehensif yang mempelajari hubungan antara organisme dan lingkunganya.

Buku ajar merupakan salah satu sumber pembelajaran bagi mahasiswa calon guru. Buku ajar menurut Dick and Carey (1996) merupakan seperangkat materi/substansi pelajaran yang disusun secara sistematis, menampilkan sosok utuh dari kompetensi yang akan dikuasai oleh mahasiswa dalam kegiatan pembelajaran. Buku ajar/bahan ajar yang efektif menurut Gerlach and Ely (1980) harus memenuhi syarat 1) ketepatan kognitif, 2) tingkat berpikir, 3) biaya, 4) ketersedian bahan, dan 5) mutu teknis.

Buku ajar ekologi berbasis kearifan lokal yang dikembangkan merupakan buku ajar yang mengintegrasikan antara nilai-nilai kearifan lokal dengan konten materi ekologi. System nilai budaya tertentu. System nilai budaya itu sendiri menurut Koentjaraningrat (1987) terdiri dari konsep-konsep yang hidup dalam alam pikiran sebagai warga masyarakat menegnai hal-hal yang harus mereka anggap amat bernilai dalam hidup. Hal ini bermakna bahwa system nilai yang ada di masyarakat tersebut akan termanifestasikan dalam prilaku kehidupan masyarakat sehari-hari, baik itu terwujud dalam bentuk kearifan-kearifan lokal maupun tradisi lainnya. Selain itu kearifan lokal yang diintegrasikan ke dalam materi ekologi adalah terkait dengan keadaan ekologi lokal seperti pertanian, perikanan, hutan, dan laut.

Kajia empiris ditemukan bahwa, saat ini belum pernah disusun suatu buku ajar ekologi dengan memanfaatkan kearifan lokal Nusa Tenggara Barat. Oleh karena itu, penelitian ini dilakukan untuk memetakan berbagai jenis kearifan lokal dari masyarakat Nusa Tenggara Barat sehingga dapat menjadi dasar untuk mengembangkan buku ajar ekologi.

\section{Metode Penelitian}

Penelitian ini menggunakan metode deskriptif dengan teknik wawancara terhadap budayawan di Pulau Lombok dan Pulau Sumbawa serta masyarakat setempat. Sebagai informan dari 
penelitian ini yaitu budayawan Lombok, antara lain Ketua Pengemban Budaya Sasak Kota Mataram dan Ketua Pengemban Budaya Sasak Kabupaten Lombok Tengah, Budayawan Pulau Sumbawa dan akademisi yang bergerak di bidang kearifan lokal.

Adapun instrumen penelitian yang digunakan yaitu pedoman wawancara, catatan lapangan dan kamera untuk alat dokumentasi.Prosedur penelitian dimulai dengan melakukan wawancara terhadap budayawan di Pulau Lombok dan Pulau Sumbawa untuk menggali informasi terkait kearifan lokal daerah. Setelah mendapatkan informasi tersebut, dilakukan pengambilan data berikutnya ke tempat dimana berlangsung kegiatan yang memuculkan kearifan lokal tersebut. Wawancara dilakukan pada bulan April 2016 selama 2 minggu.

Lokasi pengambilan data yaitu di Kabupaten Lombok Tengah, Kota Mataram, Kabupaten Sumbawa dan Kabupaten Bima, Provinsi Nusa Tenggara Barat.

\section{Hasil dan Pembahasan}

Kearifan lokal Pulau Lombok :

\section{Pemeliharaan Hutan Adat Desa Bayan}

Hutan adat di kawasan kaki Gunung Rinjani khususnya di Kecamatan Bayan, Kabupaten Lombok Utara dikelola langsung oleh masyarakat Wetu Telu Bayan. Mereka mempunyai suatu peraturan yang dikenal sebagai awig-awig dan tetap terpelihara hingga sekarang. Bagi mereka yang melanggar awig-awig pemeliharaan hutan, maka akan diberikan sanksi sesuai hukum adat yang telah ada (Jayadi et al., 2014).

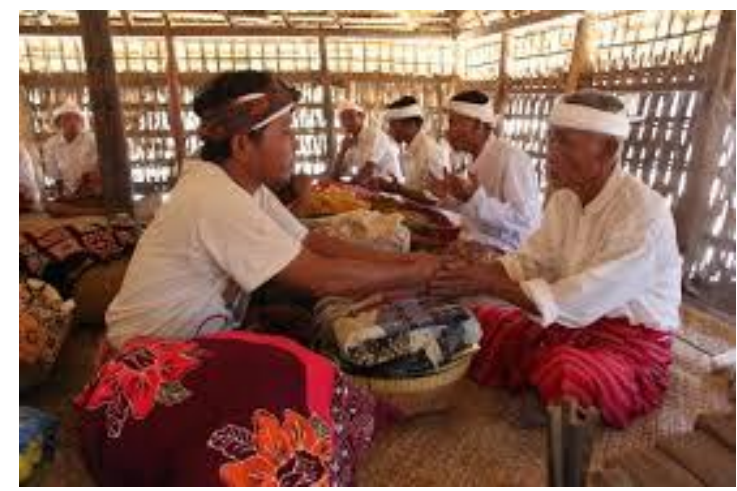

Gambar 1. Komunitas Adat Bayan

Masyarakat adat suku sasak di lombok memandang hutan pada dasarnya terbagi dalam dua kawasan yakni pawang dan gawah. Pawang merupakan kawasan hutan yang dikeramatkan dimana terdapat sekumpulan pepohonan besar yang biasanya terdapat sumber mata air sehingga tidak dapat diganggu sama sekali. Sedangkan gawah merupakan daerah yang diaman terdapat pepohonan dan aneka satwa sebagai tempat berburu dapat dikelola dan dioetik hasilnya secara kestari atas ijin dari pemangku.

Dalam kesederhanaan cara pandang tersebut terkandung kearifan terhadap kelestarian lingkungan. Penggolongan suatu kawasan hutan sebagai pawang merupakan mekanisme untuk melindungi dan melestarian fungsi hutan sebagai daerah tangkapan air yang termasuk sebagai kawasan yang dilindungi. Sedangkan gawah merupakan kawasan hutan yang menjadi salah satu sumber penghidupan yang dimanfaatkan dan diambil hasinya secukupnya sesuai dengan kebutuhan masyarakat dan jauh dari niatan eksploitasi untuk dijual ke pasar dan komoditi.

Kearifan lokal ini menggambarkan bagaimana seharusnya menjaga keberlansungan kelestarian hutan, sehingga ekosistem dalam hutan dapat terjaga dan tidak rusak. 
Keberadaan awik-awik dalam pelestarian hutan khusnya di daerah Bayan menjadi jaminan kelestaria hutan dan menjaga keseimbangan ekosistem alam.

\section{Tradisi Bau Nyale}

Tradisi "Bau Nyale" merupakan salah satu tradisi turun-temurun yang rutin digelar oleh masyarakat Lombok. Bau berarti menangkap dan Nyale berarti sejenis cacing laut. Nyale yang ditangkap dibungkus dengan daun kelapa dan dibakar untuk dijadikan sayur. Sisa pembakaran ini biasanya oleh masyarakat diletakkan di tengah tanaman sawah untuk mengusir hama karena aromanya yang tidak disukai.

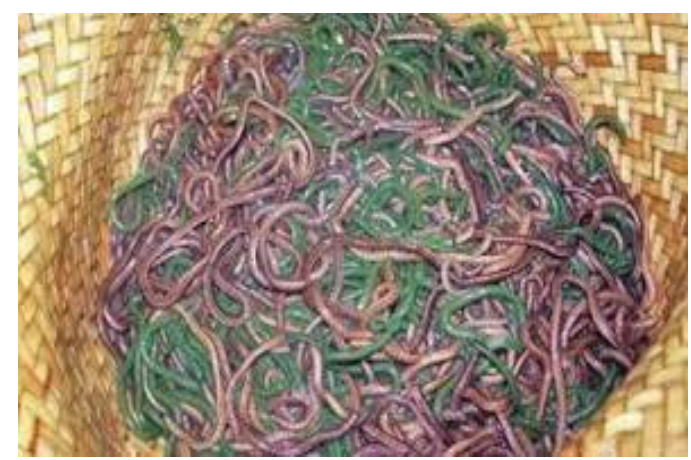

Gambar 2. Nyale (cacing laut)

\section{Membersihkan Lantai Rumah dengan Kotoran Sapi}

Kebiasaan masyarakat Dusun Sade, Lombok Tengah cukup unik yaitu lantai rumahnya yang berbahan dasar tanah sari (tanah gunung) dilumuri dengan kotoran sapi. Hal ini dilakukan oleh masayarakat dengan tujuan agar lantai tanah tidak berdebu dan menyebabkan kotor. Kegiatan mengepel dengan kotoran sapi ini dilakukan bervariasi tergantung kebutuhan, biasanya sekali dalam seminggu. Bagi masyarakat setempat, sapi sangat dekat dengan kehidupan sehari-hari yaitu untuk mengelola sawah. Hal ini karena mayoritas masyarakat Pulau Lombok berprofesi sebagai petani.

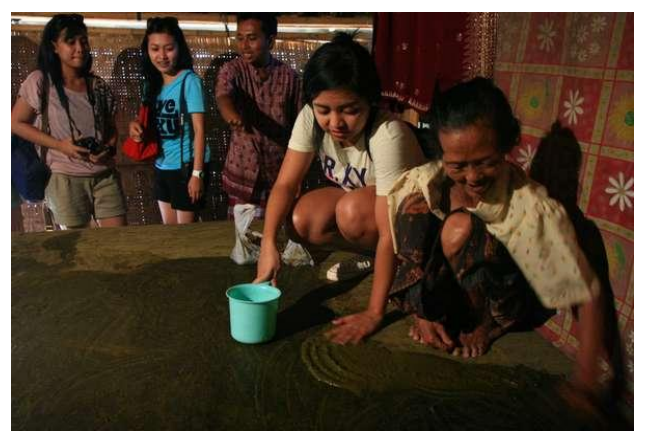

Gambar 3. Membersihkan lantai rumah dengan kotoran sapi

\section{Penggunaan Daun Mindi sebagai Pestisida Alami}

Tanaman mindi (Melia azedarach linn.) telah dikenal oleh masyarakat Tete Batu, Lombok Timur sebagai insektisida alami. Aroma dan baunya yang menyengat sangat tidak disukai oleh hama wereng. Sekali penyemprotan membutuhkan 100-200 lembar daun mindi. Tanaman mindi tergolong tumbuhan perdu yang tumbuh liar atau sengaja ditanam sebagai pelindung pada perkebunan kopi dan teh. Hampir seluruh bagian tumbuhan ini telah dimanfaatkan dalam pengobatan berbagai penyakit secara tradisional. Daun, buah, kulit batang dan kulit akar tumbuhan ini dijadikan bubuk kemudian diseduh dengan air panas untuk digunakan sebagai obat diare, cacing, dan penyakit lainnya. Hasil skrining fitokimia 
dari daun tanaman ini menunjukkan terdapatnya senyawa metabolit sekunder seperti steroid, alkaloid, fenol, flavonoid, polifenol dan glikosida (Pokhrel et al., 2015).

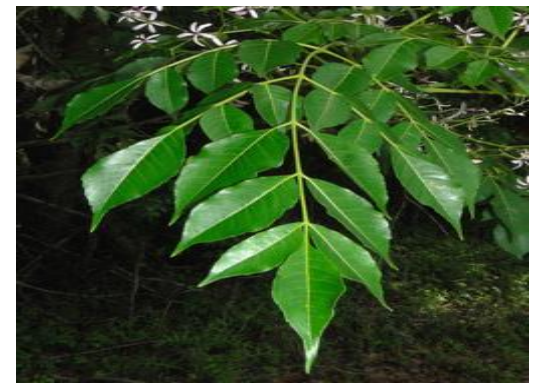

Gambar 4. Daun Tanaman Mindi

\section{Kearifan lokal di Pulau Sumbawa: Aturan Adat Mungka}

Suku samawa di Sumbawa, menjaga hutan mereka dengan aturan adat yang bernama Mungka. Mungka merupakan kegiatan menjaga hutan larangan oleh masyarakat adat yang sekaligus dilaksanakan ketika mereka mencari nafkah dalam kawasan hutan seperti berburu dan mencari tumbuhan obat. Kegiatan ini diatur dengan aturan adat, yaitu Biat. Bila ditemukan ada yang menebang pohon yang belum cukup umur akan dikenakan sanksi dan denda. Sanksinya berupa orang tersebut harus menanam pohon yang sama sebanyak 3 pohon sedangkan dendanya biasanya harus menyediakan hewan sebagai korban yang nantinya akan dimakan bersama oleh masyarakat dan juga orang tersebut dilarang untuk masuk kawasan hutan selama satu tahun.

\section{Kearifan Masyarakat Teluk Saleh}

Teluk Saleh, salah satu tempat wisata favorit yang ada di Nusa Tenggara Barat tidak hanya menghadirkan pesona alam lewat pasir putih serta biru lautnya, tetapi beragam kekayaan alam yang dapat dimanfaatkan oleh masyarakat Teluk Saleh yang sebagian besar berprofesi sebagai nelayan.atkan waktu surut ar laut untuk menangkap kanjepan Masyarakat pesisir Teluk Saleh biasanya memanfaatkan waktu surut air laut untuk menangkap kanjepang atau kerang berekor. Cara penangkapannya pun terbilang sangat mudah tanpa menggunakan bahan kimia.Cukup bermodalkan cangkul untuk menggali sekitar pesisir pantai yang banyak dihuni oleh kerang berekor yang terkenal memliki sumber protein yang cukup tinggi.

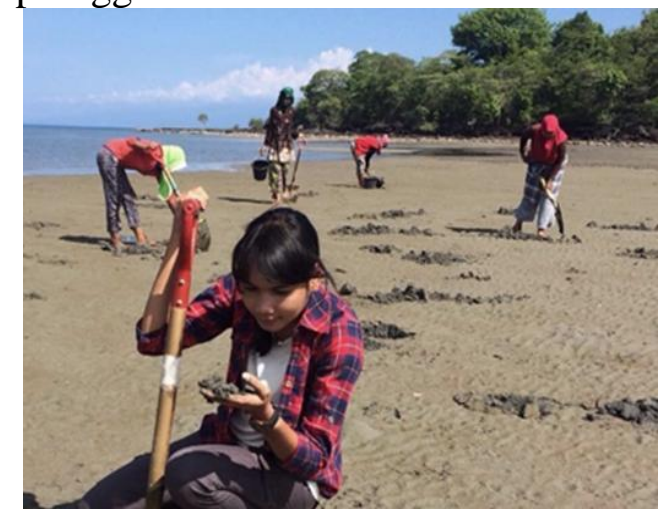

Gambar 5. Menangkap kerang berekor di Teluk Saleh

\section{Ketahanan Pangan dalam Tradisi Ampa Fare}

Tradisi Ampa Fare merupakan sebuah ritual menyimpan padi di uma lengge (rumah kerucut) yang dilakukan oleh masyarakat Desa Maria, Kabupaten Bima, Nusa Tenggara Barat. Ampa Fare diambil dari dua kata yaitu Ampa yang berarti mengangkat, 
mengangkut atau menaikkan sesuatu ke atas, dan Fare yang berarti padi atau hasil bumi. Uma lengge berbentuk kerucut, atap dan dindingnya terbuat dari alang-alang, memiliki tiga lantai, diaman lantai 1 merupakan tempat duduk-duduk, lantai 2 tempat menyimpan palawija dan lantai 3 tempat menyimpan padi. Tradisi ini diperkuat dengan adanya legenda Fare Ma Lingi (padi menangis) menunjukkan tingginya penghormatan masyarakat Bima akan padi.

\section{Kesimpulan}

Kearifan lokal yang terdapat di Nusa Tenggara Barat kaitannya dengan ilmu ekologi khususnya di Pulau Lombok diantaranya pemeliharaan hutan adat Bayan, tradisi Bau Nyale, membersihkan lantai rumah dengan kotoran sapi, dan penggunaan daun mindi sebagai insektisida alami. Sementara di Pulau Sumbawa diantaranya Aturan adat Mungka, Kearifan masyarakat pesisir Teluk Saleh dan ketahanan pangan dalam tradisi Ampa Fare. Nilai kearifan lokal tersebut dapat dijadikan sebagai dasar dalam pengembangan buku ajar ekologi.

\section{Ucapan Terima Kasih}

Ucapan terima kasih untuk Ketua Pengemban Budaya Sasak Kota Mataram dan Lombok Tengah serta Budayawan Pulau Sumbawa dan akademisi yang bergerak di bidang kearifan lokal.

\section{Daftar Pustaka}

Al Wasilah, A.C., Suryadi, K dan Karyono, T. (2009). Etnopedagogi landasan praktek pendidikan dan pendidikan guru. Bandung: Kiblat.

Dick, Walter and Carey. 1996. The Systematic Design of Instructio. New York: Longman.

Gerlach, Vernon S. and Donald P. Ely. 1980. Teaching and Media: A Systematic Approach. Second Edition. Englewood Cliffs, New Jersey: Prentice Hall, Inc

Ibrahim, M. 2014. Inovasi Pembelajaran Sains Berbasis Kearifan Lokal. Makalah Disampaikan pada Seminar Nasional FPMIPA IKIP MATARAM 2014. Makalah Prosiding hal.xv -xxiv.

Jayadi, E. M., Soemarno., Yanuwiadi, B., dan Purnomo, M. (2014). Local wisdom transformation of Wetu Telu community on Bayan forest management, North Lombok, West Nusa Tenggara. Research on Humanities and Social Sciences, 4(2): 109-118.

Kurnia, N., Liliasari., Adawiyah, D. R., dan Supriyanti, F. M. T. (2016). Aspek Fungsional dan Keamanan Pangan Khas Lombok Untuk Perkuliahan Kimia Bahan Makanan. Prosiding Seminar Nasional Kimia. FMIPA Universitas Mataram

Keraf, S.A. 2002. Etika Lingkungan. Penerbit Buku Kompas. Jakarta

Koentjaraningrat. 1987. Kebudayaan, Mentalitas, dan Pembangunan. Jakarta: Gramedia.

Pokhrel, B., Raut, S., dan Rijal, S. (2015). Phytochemical screening, antimicrobial and antioxidant activity of Melia azedarach leaves in methanol solvent. World Journal of Pharmacy and Pharmaceutical Sciences, 4(7): 1562-1575.

Suardana, I.Y. (2010). Pengembangan model praktikum kimia dasar berbasis budaya Bali untuk meningkatkan keterampilan berpikir kritis mahasiswa calon guru kimia. (Disertasi). Sekolah Pascasarjana, Universitas Pendidikan Indonesia, Bandung.

Sudiatmika, A.A.I.R. (2010). Pengembangan alat ukur tes literasi sains siswa SMP dalam konteks budaya Bali. (Disertasi). Sekolah Pascasarjana, Universitas Pendidikan Indonesia, Bandung.

Susanti, I.L.M.A. (2013). Developing digital storytelling based local wisdom through blended learning as an innovative media for teaching English at eighth grade students of SMP Negeri 1 Petang in the academic year 2012/2013. Asia-Pasific Collaborative Education Journal, 9 (2), hlm. 95-102. 